\title{
The Effect of Self Efficacy and Parent Support on Learning Motivation in Management Business Students in Padang's Private Vocational School
}

\author{
Ummul Hasanah, Alizamar Alizamar, Marjohan Marjohan, Engkizar Engkizar
}

Universitas Negeri Padang

engkizar_quran@yahoo.com

Submitted: 2019-10-23, Revised: 2019-11-18, Accepted: 2019-11-26

\begin{abstract}
This study departs from the expectation that high or low student learning motivation are influenced by self-efficacy and family environment. The results of the study show that: 1) self-efficacy has a significant effect on learning motivation. 2) self-efficacy and parental support have a significant effect on learning motivation. This research is an associative descriptive study. The sample in this study is the business management students of class X and XI that are registered at Padang Private Vocational School. The findings from this study are expected to be a reference for teachers and other academic communities to be able to pay more attention to students in learning by giving attention to the family environment and paying attention to their learning attitudes and also help increase student motivation in learning so that maximum learning outcomes are obtained.
\end{abstract}

Keywords: Learning Motivation; Parent Support; Self-Efficacy

\section{Introduction}

Education has a very important role for individuals, families, communities, and for the country(Sudarsana, 2016). The uture education of an individual person will be more secure so that family welfare will be guaranteed as well. For the community, the education pursued by an individual will help solve problems that exist in society. Therefore, education is very necessary to be developed, because quality education can increase the intelligence of a nation. Education is a process in order to influence students to be able to adjust as well as possible with their environment so that it will cause changes in students (Murniyettiet al. 2016; Sumantri, 2014). Previous research found support for learning had a positive influence on personality and career. This focused on general self-efficacy (Phillips \& Gully, 1997; Porter, 2005; Payne et al., 2007: Damri, et al. 2017; Engkizar et al. 2018)

Achieving educational goals are influenced by many factors, including motivation. Sardiman (2012) explains that motivation can also be said in a series of efforts to provide certain conditions so that someone wants and wants to do something, and if he does not like it, he will try to negate or avoid feelings of dislike. Ormrod (2008) which explains that motivation can turn on, direct, maintain behavior to make students move, place students in a certain direction, and keep students moving. In addition, Slavin (2011) explains that motivation is something that causes students to step, keeps students moving, and determines which direction students try to move. So, motivation plays an important role in encouraging students to learn.

The role of the teacher as a counselor is closely related to student motivation in learning. Students who have been learning difficulties will have low learning motivation. The role of the counselor teacher (counselor) to help students overcome learning difficulties, so that student learning motivation will increase. In addition, the motivation possessed by students can come from within (intrinsic) and from outside (extrinsic). Jahja (2011), Yusnitaet al. (2018) explained that one of the factors that influence student motivation is extrinsic in the form of external encouragement given by parents, teachers, and society. Thus the teacher as a counselor (counselor) also has a role to increase student learning motivation.

Today many students choose to continue their education to vocational school (Kusnadi \& Haryadi, 2010). In the National Education System Law Article 15 of the Ministry of 
National Education (2006) it is stated that vocational education is secondary education that prepares students to work in certain fields. This means that one of the goals of students to study in vocational schools is so that students are better prepared to enter the workforce.

Before entering the world of work, students must prepare in advance the needs and needs of workesr in the future. Good learning will help students enter the workforce. However, the fact is that there are many complaints about the decline in student motivation today, both in primary, secondary and tertiary schools (Waruwu, 2006). From the research conducted by Rahmi (2012) it was revealed that only $15.3 \%$ of SMK students were highly motivated. Though motivation has an important role to overcome student learning difficulties, student work readiness, and to achieve educational goals.

Another stimulation that influences learning motivation is self-efficacy. This is supported by the findings of Ghufron and Risnawita (2010) 'study that self-efficacy is a form of motivation. Another study was also conducted by Zimmerman (2000) and found the results that self-efficacy has a relationship to learning motivation. Even Lestari and Afifah's (2016) research found that there was a significant effect of self-efficacy on learning motivation. Selfefficacy is the belief that someone can achieve the desired results, such as mastering a new skill or achieving a goal (Wade \& Tavris, 2007; Agusti et al. 2018).

Another factor that influences learning motivation is parental support (Archara \& Shobna, 2011; Slameto, 2010; Hutagalung, 2005). Nugrahini and Margunani (2015) found that there was a significant influence between family environment and learning motivation. Based on interviews with guidance teachers (counselors) at KotaPadang Private Vocational School it is known that $49 \%$ of students come from Broken Home families. This means that almost half of the students' needs for family integrity are not fulfilled. To get initial information about parental support, the researcher gave a questionnaire to 30 students, the initial data was obtained, it was known that students had a good relationship with parents, but parents were indifferent towards learning children at home. More parents don't pay attention to learning their children. Thus, the support of parents for children's learning is still low. Thus one of the causes of low learning motivation is due to low parental support.

Based on these phenomena, the research is directed at learning motivation, selfefficacy, and family environment. Allegedly high or low student motivation is influenced by self-efficacy and family environment.

\section{Methods}

This research is descriptive associative. This study analyzes the effect of three independent variables, namely self-efficacy $\left(\mathrm{X}_{1}\right)$ for Elderly Support $\left(\mathrm{X}_{2}\right)$ which affects learning motivation (Y). Analysis was carried out using linear regression. The population for this study is all business management students of class X and XI that are registered at Padang Private Vocational School. The number of business management students in class X and XI registered at Padang Private Vocational School is 296 students. Overall, the instrument of this study consisted of 81 item statements.

\section{Results and Discussion}

The results of the analysis of the contribution of self-efficacy and parental support to learning motivation can be seen in Table 1. 
Table 1. Results of Multiple Regression Analysis and Significance $\left(\mathrm{X}_{1,2}\right)$ against (Y)

\begin{tabular}{cccc}
\hline Model & R & R Square & Sig. \\
\hline X.Y & 0.692 & 0.475 & 0.000 \\
\hline
\end{tabular}

Based on the analysis of the table above there is a significant value of 0.000 which states that it is smaller than $0.05(0.000<0.05)$, so it can be concluded that the variables selfefficacy $\left(\mathrm{X}_{1}\right)$ and parental support $\left(\mathrm{X}_{2}\right)$ on learning motivation $\left(\mathrm{X}_{3}\right)$. Besides that the value of $\mathrm{R}$ is 0.692 , this indicates the regression coefficient between self-efficacy and parental support for motivation to learn. It can be seen that the R Square value is 0.475 . This means that selfefficacy $\left(\mathrm{X}_{1}\right)$ and parental support $\left(\mathrm{X}_{2}\right)$ contribute $47.5 \%$ to learning motivation, while the remaining $52.5 \%$ is influenced by other variables that cannot be explained in this study. Furthermore to see the regression equation can be seen in Table 2 below.

Table 2. Equations of Regression and Significance of $X_{1}$ and $X_{2}$ towards $Y$

\begin{tabular}{lll}
\hline & \multicolumn{2}{l}{ Unstandardized Coefficients } \\
\cline { 2 - 3 } & B & Std. Error \\
\hline (Constant) & 49.996 & 5.092 \\
Self-efficacy & 0.678 & 0.042 \\
\hline Parents Support & 0.068 & 0.033 \\
\hline
\end{tabular}

In Table 2 above, the value of constant (a) is 49,996, while the self-efficacy value is 0,678 and parental support is 0.068 , so the regression equation becomes: $\hat{Y}=10.363+$ $0.678 \mathrm{X}_{1}+0.068 \mathrm{X}_{2}$. This regression formula shows that every one-point increase in learning motivation, accompanied by an increase in self-efficacy of 0.678 and accompanied by an increase in parental support of 0.068 . The regression coefficient is positive, so it can be stated that the effect of the variable self-efficacy $\left(\mathrm{X}_{1}\right)$ and parental support $\left(\mathrm{X}_{2}\right)$ on the value $(\mathrm{Y})$ is positive, which means that self-efficacy and parental support will cause an increase in student motivation. Next is the description of self-efficacy $\left(\mathrm{X}_{1}\right)$ and parental support $\left(\mathrm{X}_{2}\right)$ on learning motivation $\left(\mathrm{X}_{3}\right)$.

Self efficacy $\left(\mathrm{X}_{1}\right)$ Parent Support $\left(\mathrm{X}_{2}\right)$ and learning motivation $(\mathrm{Y})$

This study analyzes the effect of 3 independent variables, namely self efficacy $\left(X_{1}\right)$ for Elderly Support $\left(\mathrm{X}_{2}\right)$ which affects learning motivation (Y). Based on the data analysis carried out in this study, data were obtained about the Effect of Self Efficacy and Parental Support on the Learning Motivation of Business Management in Padang City Private Vocational Schools. The effect of Self Efficacy on the Learning Motivation of Management Business Students in Padang City Private Vocational School can be seen in Table 1 below: 
Table 3. Frequency Distribution and Percentage of Self Efficacy $\left(\mathrm{X}_{1}\right)(\mathrm{n}=296)$

\begin{tabular}{llll}
\hline $\begin{array}{l}\text { Interval } \\
\text { Score }\end{array}$ & Category & F & \% \\
\hline$\geq 96$ & Very High & 109 & 36.82 \\
$76-95$ & High & 164 & 55.41 \\
$56-75$ & Medium & 23 & 7.77 \\
$36-55$ & Low & 0 & 0.00 \\
$\leq 35$ & Very Low & 0 & 0.00 \\
Total & & 296 & 100 \\
\hline
\end{tabular}

The table above shows that the majority of students have high self-efficacywhich is equal to $55.41 \%$, some of the other students are in the very high category of $36.82 \%$, then in the moderate category of $7.77 \%$. The results of this study are in line with the research conducted by Lestari and Afifah (2014). The results showed that there was an effect of selfefficacy on achievement motivation.

Self-efficacy is a key element in supporting the need to achieve success. Bandura (Ghufron\&Risnawita, 2010) explains that self-efficacy is the result of cognitive processes in the form of beliefs, decisions, or awards regarding the ability of students to carry out certain tasks or actions to achieve the desired results. Self-efficacy is a key element in supporting the need to achieve success. Bandura (Ghufron\&Risnawita, 2010) explains that self-efficacy is the result of cognitive processes in the form of beliefs, decisions, or awards regarding the ability of students to carry out certain tasks or actions to achieve the desired results.

Table 4. Frequency Distribution and Percentage of Parent Support $\left(X_{2}\right)(n=296)$

\begin{tabular}{llll}
\hline $\begin{array}{l}\text { Interval } \\
\text { Score }\end{array}$ & Category & F & \% \\
\hline$\geq 96$ & Very high & 90 & 30.41 \\
$76-95$ & High & 167 & 56.42 \\
$56-75$ & Medium & 38 & 12.84 \\
$36-55$ & Low & 1 & 0.34 \\
$\leq 35$ & Very low & 0 & 0.00 \\
Total & & 296 & 100 \\
\hline
\end{tabular}

The table above shows that most students have high parental support which is equal to $56.42 \%$, some of the other students are in the very high category of $30.41 \%$, for the medium category is $12.84 \%$ and then in the low category of $0.34 \%$.

Table 5.Frequency Distribution and Percentage of Learning Motivation(Y) $(n=296)$

\begin{tabular}{llll}
\hline $\begin{array}{l}\text { Interval } \\
\text { Score }\end{array}$ & Category & F & \% \\
\hline$\geq 96$ & Very high & 88 & 29.73 \\
$76-95$ & High & 198 & 66.89 \\
$56-75$ & Medium & 9 & 3.04 \\
\hline
\end{tabular}




\begin{tabular}{llll}
\hline $36-55$ & Low & 1 & 0.34 \\
$\leq 35$ & Very low & 0 & 0.00 \\
Total & & 296 & 100 \\
\hline
\end{tabular}

The table above shows that most students have a high learning motivation that is equal to $66.89 \%$, some of the other students are in the very high category of $29.73 \%$, for the medium category is $3.04 \%$ and then in the low category of $0.34 \%$.

Previously, the author has touched that self-efficacy is a person's self confidence in his ability to plan and carry out an action to achieve a goal. The results of this study have clearly succeeded in knowing that overall student self-efficacy is in the high category, meaning that students have a high level of self-confidence to be able to complete the assignments of lectures. According to the author, in college students are certainly faced with a variety of academic assignments, so high confidence in their abilities is a basic capital for achieving academic achievement.

The results of this study are supported by several previous studies which prove that self-efficacy greatly affects one's success in achieving planned goals (Mulki et al. 2008). The higher one's self-efficacy in carrying out a given task, the greater the chance of success he will get (Galloway \& Lang, 2014). In other words the presence of self-efficacy in themselves is very instrumental in determining the success or failure of someone in carrying out the tasks that have been charged.

As stated by Bandura (2010) self-efficacy really determines how strong effort, persistence, tenacity are employed by someone in a job. In addition, self-efficacy will also influence someone to deal with work obstacles, manage stress and anxiety so that they can find solutions to continue to pursue success. Someone with low self-efficacy, will tend to be vulnerable in the face of pressure, depression, and lack of confidence. Someone with high self-efficacy tends to be calm in facing difficult tasks and situations.

This study presents the effect of self-efficacy and parental support on the motivation of Business Management Students of Private Vocational Schools in Padang. This is a match between the findings in this study with the phenomenon in the field. The implications of the results of this study emphasize the tangible benefits of the results of the study to increase the motivation of Business Management Students of Vocational Schools in Padang. Some of the strategic implications of the results of this study are as follows: 1) This study proves that the variable self efficacy has a positive and significant effect on the motivation of Business Management Students of Vocational Schools in Padang. This proves that high self efficacy can make students confident of their abilities and potential to complete a business or work that will have an impact on success. The increasing self efficacy, the higher the motivation of students

2) This research also proves that parental support has a considerable influence to increase student motivation in school. Therefore, the higher the support from parents, the more motivation to learn at school.

\section{Conclusions and Suggestions}

Based on the results of the study, related to Self-Efficacy, it can be concluded that SelfEfficacy has a positive effect on the learning motivation of students in Management Business Private Vocational Schools in the city of Padang. The results of this study indicate that the higher the self-efficacy, the higher the learning motivation of students in the Management Business Private Vocational School in the city of Padang. And in terms of Parental Support, it can be concluded that parental support has a positive effect on the learning motivation of students in the Management Business Private Vocational School in the city of Padang. So 
that it is expected that parents provide confidence and support for their children, so they can face difficult situations both in lessons and in other activities. Because parental support and self-confidence greatly influence motivation in learning and dealing with things.

\section{References}

Agusti, F. A., Zafirah, A., Engkizar, E., Anwar, F., Arifin, Z., \&Syafril, S. (2018). The Implantation of Character Values toward Students through Congkak Game for Mathematics Instructional Media. JurnalPenelitian Pendidikan, 35(2), 132-142.

Archara, N., \& Shobhna, J. (2011). "Achievement Motivation and Parental Support to Adolescents". Journal of the Indian Academy of Applied Psychology 37 (1), 132-139.

Bandura, A. (2010). Self-efficacy. The Corsini encyclopedia of psychology, 1-3.

Damri, D., Engkizar, E., \& Anwar, F. (2017). Hubungan Self-Efficacy dan ProkrastinasiAkademikMahasiswaDalamMenyelesaikanTugasPerkuliahan. JURNAL EDUKASI: JurnalBimbinganKonseling, 3(1), 74-95.

Engkizar, E., Alfurqan, A., Murniyetti, M., \& Muliati, I. (2018). Behavior and Factors Causing Plagiarism among Undergraduate Students in Accomplishing the Coursework on Religion Education Subject. Khalifa Journal of Islamic Education, 1(1), 98-112.

Ghufron, M. Nur dan Rini Risnawita S. (2010). Teori-Teori Psikologi. Jogjakarta: Ar-ruzz Media.

Galloway, M. K. (2014). James M. Lang: Cheating Lessons: Learning from Academic Dishonesty. (Cambridge, MA: Harvard University Press, 2013. Pp. i, 256.). The Review of Politics, 76(3), 533-535.

Hutagalung, L. (2005). Motivasi Belajar Mengajar. Jakarta: Raja Grafindo.

Jahja, Yudrik. (2011). PsikologiPerkembangan. Jakarta: KencanaPrenada Media.

Kusnadi, M., \& Haryadi, S. (2010). Perbedaan perencanaan karir siswa SMK dan SMU. Universitas Muhammadiyah Surakarta.

Lestari, Wahyu Puji dan Dian Ratnaningtyas Afifah. (2014). Pengaruh Self Efficacy Dan Kecerdasan Emosi Terhadap Motivasi Berprestasi Siswa SMK PGRI 1 Madiun. Jurnal Counsellia Vol 4, No 2 (2014).

Mulki, J. P., Lassk, F. G., \& Jaramillo, F. (2008). The effect of self-efficacy on salesperson work overload and pay satisfaction. Journal of Personal Selling \& Sales Management, 28(3), 285-297.

Murniyetti, M., Engkizar, E., \& Anwar, F. (2016). Pola Pelaksanaan Pendidikan Karakter Terhadap Siswa Sekolah Dasar. Jurnal Pendidikan Karakter, 6(2).

Nugrahini, Rizki Widya dan Margunani. (2015).Pengaruh Lingkungan Keluarga Dan Pemanfaatan Internet Sebagai Sumber Belajar terhadap Motivasi Belajar Siswa Pada Mata Pelajaran Ekonomi Di SMANegeri 5 Semarang. Jurnal Pendidikan Ekonomi Dinamika Pendidikan, Vol. X No. 2 Desember 2015 Hal. 172 - 187.

Ormrod, Jeanne Ellis. (2008). Educational Psychology. Amerika: Pearson Education.

Phillips, J. M., \& Gully, S. M. (1997). Role of goal orientation, ability, need for achievement, and locus ofcontrol in the self-efficacy and goal-setting process.Journal of Applied Psychology, 82, 792-802. 
Porter, C. (2005). Goal orientation: Effects on backing up behaviour, performance, efficacy, and commitment inteams.Journal of Applied Psychology, 90, 811-818.

Payne, S. C., Youngcourt, S. S., \& Beaubien, J. M. (2007). A meta-analytic examination of the goal orientation nomological net. Journal of applied psychology, 92(1), 128.

Sardiman, A.M. (2012). Interaksi \& Motivasi Belajar Mengajar. Jakarta: Raja Grafindo Persada.

Slameto. (2010). Belajar \& Faktor-Faktor Yang Mempengaruhinya. Jakarta: Rineka Cipta.

Slavin, Robert E. (2011). Psikologi Pendidikan Teori dan Praktek ed.9 Jilid 2. Jakarta: Indeks. 
